\title{
Anti-Oxidative Effect of Aqueous Garlic Extract (AGE) on Androgen Induced Changes in Ovaries of Prepubertal Female Rats
}

\section{Yasmeen Bashir, ${ }^{1}$ Nabeela Habib, ${ }^{2}$ Samar Ashraf ${ }^{3}$}

\begin{abstract}
Objectives: It has been documented that the administration of exogenous androgens to immature female rats produces polycystic ovaries. There is a substantial reduction of antioxidants in this condition, with an elevated risk of oxidative stress. The current research is intended to evaluate these effects and to assess the protection provided by aqueous garlic extract (AGE).

Methods: An experimental study conducted at University of Health Sciences, Lahore. The data was collected over a period of one month. Fifty female prepubertal rats, 21 days of age, were divided into five groups, A, B, C, D and E. Group A served as control. Group B received testosterone propionate (TP) subcutaneous for 14 days and served as disease control. Group C received testosterone propionate (TP) subcutaneous for 14 days and concomitantly Aqueous garlic extract (AGE). Group D receive testosterone propionate (TP) subcutaneous for 14 days and Aqueous garlic extract (AGE) from day 14-21. Group E received testosterone propionate (TP) subcutaneous for 14 days with no intervention till day 21 . Blood samples of 50 female rats were drawn by doing cardiac puncture and clear serum was collected by centrifugation. This serum was used to assess the Catalase enzyme by using specific commercial kits.

Results: The concentration and activity of catalase enzyme in the female rats with polycystic ovaries showed significant decrease as compare to the healthy controls. The involvement of antioxidants to manage the polycystic ovaries may be helpful as secondary therapy to prevent oxidative damage.

Conclusion: The results showed that AGE with its antioxidative properties not only prevents the damage caused by oxidative stress, it also increased the level of serum catalase that helps to create a balance between beneficial oxidant generation and damaging oxidative stress.

Key words: Androgens, immature female rats, ovaries, antioxidants, oxidative stress, aqueous garlic extract (AGE), Catalase.

How to cite: Bashir.Y., Habib N. Ashraf.S. Anti-Oxidative Effect of Aqueous Garlic Extract (AGE) on Androgen Induced Changes in Ovaries of Prepubertal Female Rats. Esculapio. 2021.17(01):55-59
\end{abstract}

DOI: https://doi.org/10.51273/esc21.2517111

\section{Introduction}

$\mathrm{R}$ ecent research in human and non human primates suggest that elevated androgens play a significant role in the development of conditions resembling polycystic ovarian syndrome (PCOS). ${ }^{1}$

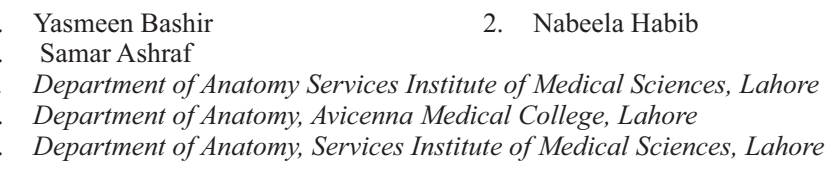

\section{Correspondence:}

Dr. Yasmeen Bashir, Department of Anatomy Services Institute of Medical Sciences, Lahore.Email:yasmeen.javed75@gmail.com
Early exposure of androgens in young females, either due to environmental or genetic factors can cause polycystic ovarian syndrome (PCOS). ${ }^{2}$

Rodent models of polycystic ovaries have shown many characteristics similar to that in the human polycystic ovarian syndrome (PCOS) which includes hyperandrogenism, disrupted cyclicity, presence of follicular cysts/polycystic ovaries. ${ }^{3}$ Different androgens were used to develop polycystic ovaries in rodents like Dihydrotestosterone (DHT), estradiol-valerate, dehydroepiandrosterone (DHEA), and testosterone. ${ }^{4}$ In this study we used Testosterone propionate (TP) to develop a rodent model of the condition.

Oxidative stress (OS) has been found to play a signi- 
ficant role in the pathophysiology of Polycystic Ovarian Syndrome (PCOS). ${ }^{5}$ The imbalance between oxidants and antioxidants is commonly referred as oxidative stress. When the imbalance favors the oxidants, generation of excessive amounts of reactive oxygen species harm our body in various ways. ${ }^{5}$ Oxidants, which exist in two categories: reactive oxygen species (ROS) and reactive nitrogen species (RNS), are exposed to biological systems living in aerobic environments. Chemical species that are formed upon incomplete reduction of oxygen include superoxide anion (O2-), hydrogen peroxide $\left(\mathrm{H}_{2} \mathrm{O}_{2}\right)$, and hydroxyl radical $(\mathrm{OH})^{6}$. Under normal conditions, scavenging molecules commonly known as antioxidants prevent overproduction of reactive oxygen species (ROS) by converting it to $\mathrm{H}_{2} \mathrm{O}$. There are two types of antioxidants in the human body: enzymatic and non-enzymatic antioxidants. ${ }^{7}$ Enzymatic antioxidants or natural antioxidants neutralize excessive reactive oxygen species (ROS) and prevent it from destroying the cellular structure. Enzymatic antioxidants collectively constitute catalase, superoxide dismutase and glutathione peroxidase. Non-enzymatic or synthetic antioxidants include vitamins and minerals which neutralize reactive oxygen species (ROS) directly, such as vitamin C, vitamin E, zinc, taurine and beta carotene. ${ }^{8}$

Allium Sativum (Garlic) is one of the herbs used in the everyday life of Asian countries, whether in raw or cooked form. Raw garlic homogenate is the main preparation of garlic used in various scientific studies, since it is the usual way of garlic consumption. Garlic is known to contain natural antioxidants that can remove reactive oxygen species (ROS). ${ }^{9}$ Garlic has been shown to have several medicinal properties, including antioxidative, antithrombolytic, ${ }^{10}$ cancer preventive, ${ }^{11}$ and cardio-protective effect. ${ }^{12}$ The antioxidant effect of garlic extract by scavenging reactive oxygen species increases the levels of cellular antioxidant enzymes; superoxide dismutase (SOD), catalase (CAT) and glutathione peroxidase (Gper) in the cells. ${ }^{13}$

Raw garlic homogenate has been documented to increase the development of endogenous antioxidants and minimize lipid peroxidation in the liver, kidney and heart of rats in a dose-dependent manner. ${ }^{14}$ It is very helpful in treating many conditions related to the male reproductive system. Therefore, the purpose of this research is to evaluate the antioxidative effect of aqueous garlic extract on Testosterone propionate (TP) induced changes in ovaries of prepubertal female rats.

\section{Methods}

An experimental study conducted at University of Health Sciences, Lahore. The data was collected over a period of one month. 50 female prepubertal albino rats, 21 days of age and 40-50gms in weight, were obtained from colonies raised at the Animal House, University of Health Sciences, held at a controlled temperature of $25^{\circ} \pm 2{ }^{\circ} \mathrm{C}$, humidity $55 \pm 5$ and light and dark cycles of 12 hours each. The animals were fed on standard rat diet and tap water ad libitum. The experiment was carried out in accordance with the

Table 1: Showing Intervention and Dosage Schedule

\begin{tabular}{|c|c|c|c|c|}
\hline $\begin{array}{c}\text { GROUPS } \\
\mathbf{N}=10\end{array}$ & $\begin{array}{l}\text { INTERVENTION/ } \\
\text { TREATMENT }\end{array}$ & $\begin{array}{c}\text { ROUTE OF } \\
\text { ADMINISTRATION }\end{array}$ & DURATION & SACRIFICED \\
\hline $\begin{array}{c}\text { GROUP } \\
\text { A }\end{array}$ & Propylene glycol $5 \mathrm{ml} / \mathrm{kg}$ & Subcutaneous & Day 1 to 14 & $\begin{array}{c}\text { On day } 15^{\text {th }} \text { of } \\
\text { experiment }\end{array}$ \\
\hline $\begin{array}{l}\text { GROUP } \\
\text { B }\end{array}$ & $\begin{array}{l}\text { Testosterone propionate } 10 \mathrm{mg} / \mathrm{kg} \\
\text { dissolved in } 5 \mathrm{ml} / \mathrm{kg} \text { propylene glycol }\end{array}$ & Subcutaneous & Day 1 to 14 & $\begin{array}{c}\text { On day } 15^{\text {th }} \text { of } \\
\text { experiment }\end{array}$ \\
\hline \multirow[t]{2}{*}{$\begin{array}{l}\text { GROUP } \\
\text { C }\end{array}$} & $\begin{array}{l}\text { Testosterone propionate } 10 \mathrm{mg} / \mathrm{kg} \\
\text { dissolved in } 5 \mathrm{ml} / \mathrm{kg} \text { propylene glycol }\end{array}$ & Subcutaneous & Day 1 to 14 & \multirow[t]{2}{*}{$\begin{array}{c}\text { On day } 15^{\text {th }} \text { of } \\
\text { experiment }\end{array}$} \\
\hline & Aqueous garlic extract $200 \mathrm{mg} / \mathrm{kg}$ & Oral & Day 1 to 14 & \\
\hline \multirow[t]{2}{*}{$\begin{array}{l}\text { GROUP } \\
\text { D }\end{array}$} & $\begin{array}{l}\text { Testosterone propionate } 10 \mathrm{mg} / \mathrm{kg} \\
\text { dissolved in } 5 \mathrm{ml} / \mathrm{kg} \text { propylene glycol }\end{array}$ & Subcutaneous & Day 1 to 14 & \multirow[t]{2}{*}{$\begin{array}{c}\text { On day } 22^{\text {nd }} \text { of } \\
\text { experiment }\end{array}$} \\
\hline & Aqueous garlic extract $200 \mathrm{mg} / \mathrm{kg}$ & Oral & Day 14 to 21 & \\
\hline $\begin{array}{l}\text { GROUP } \\
\text { E }\end{array}$ & $\begin{array}{l}\text { Testosterone propionate } 10 \mathrm{mg} / \mathrm{kg} \\
\text { dissolved in } 5 \mathrm{ml} / \mathrm{kg} \text { propylene glycol }\end{array}$ & Subcutaneous & $\begin{array}{c}\text { Day } 1 \text { to } 14 \\
\text { (Animals were sacrificed } \\
\text { a week later on day } 21\end{array}$ & $\begin{array}{c}\text { On day } 22^{\text {nd }} \text { of } \\
\text { experiment }\end{array}$ \\
\hline
\end{tabular}


instructions and guidelines of Ethical Committee of UHS. The animals were randomly allocated to five groups, A, B, C, D and E using balloting method containing 10 animals each. Intervention and dosage schedule is given in table 1 .

\section{Method for Blood Collection}

On day 15 of the study, animals of group A, B, and C were weighed and transferred to a bell jar one by one covered with a lid, containing a cotton swab soaked in chloroform. The animals were kept till they were completely under but still breathing; these were then placed on the dissection board in supine position. $5 \mathrm{ml}$ of blood was drawn by doing cardiac puncture with the help of 5cc disposable syringe; blood was then transferred to vacutainer and allowed it to stand for one hour, and then put these vacutainers in the centrifuge machine (EBA-20 Heittich) to centrifuge at a speed of 3000 revolutions per minute. Clear serum was then transferred by a micropipette in to sterilized eppendorf; these tubes were properly labeled before placing them in to the refrigerator set at $-20^{\circ} \mathrm{C}$. These blood samples were used to assess the serum Catalase enzyme by using specific commercial kits. Animals from group D and E were sacrificed on day 21.

\section{Chemical}

Testosterone propionate was purchased from Ipca Laboratories Ltd., Batch No.4002 TH1RN, India.The dose and method of preparation of aqueous garlic extract was adopted from the earlier work. ${ }^{15}$ Similarly the dose of TP was derived from the work reported earlier. ${ }^{4}$ Doses were adjusted according to the weight of the animals.

\section{Statistical Analysis}

The data was entered and analyzed by using SPSS 20.0. Mean \pm SD were given for the quantitative variables. One way ANOVA was applied to compare means of variables among the control and experimental groups. Post hoc Tuckey's test was applied to compare the means of groups. Chi-square test was applied to categorical variables. P-value $\leq 0.05$ is considered statistically significant.

\section{Result}

One way ANOVA test showing the difference was statistically significant when mean value of serum catalase ( $p$-value $<0.001^{*}$ ) of groups A, B, C, D and E were compared with each other. (Table 2. Fig.1). The post hoc Tukey's test was applied to analyze the comparison of mean value of serum catalase among various groups. (Table 3. Fig.1). There is significant increase in the level of serum catalase in experimental group D. The disease control group had markedly lower levels of the enzyme, whereas experimental groups had significant higher levels of the serum catalase as compared to other groups.

Table 3: Shows Multiple Comparison of Mean Value of Serum Catalase Among Various Groups

\begin{tabular}{|c|c|c|c|c|}
\hline $\begin{array}{l}\text { (I) } \\
\text { group }\end{array}$ & $\begin{array}{l}\text { (J) } \\
\text { group }\end{array}$ & $\begin{array}{c}\text { Mean } \\
\text { Difference (I-J) }\end{array}$ & $\begin{array}{l}\text { Std. } \\
\text { Error }\end{array}$ & $\begin{array}{c}\text { p- } \\
\text { value }^{* *}\end{array}$ \\
\hline \multirow[t]{4}{*}{$\mathbf{A}$} & B & .0152 & .0371 & 0.994 \\
\hline & $\mathrm{C}$ & .0101 & .0371 & 0.999 \\
\hline & D & -.1539 & .0371 & $<0.001^{*}$ \\
\hline & E & -.2111 & .0371 & $<0.001^{*}$ \\
\hline \multirow[t]{4}{*}{ B } & A & -.0152 & .0371 & 0.994 \\
\hline & $\mathrm{C}$ & -.0051 & .0371 & 1.000 \\
\hline & D & -.1691 & .0371 & $<0.001 *$ \\
\hline & E & -.2262 & .0371 & $<0.001^{*}$ \\
\hline \multirow[t]{4}{*}{ C } & A & -.0101 & .0371 & 0.999 \\
\hline & B & .0051 & .0371 & 1.000 \\
\hline & D & -.1640 & .0371 & $<0.001^{*}$ \\
\hline & $\mathrm{E}$ & -.2212 & .0371 & $<0.001 *$ \\
\hline \multirow[t]{4}{*}{ D } & A & .1539 & .0371 & $<0.001 *$ \\
\hline & B & .1691 & .0371 & $<0.001^{*}$ \\
\hline & $\mathrm{C}$ & .1640 & .0371 & $<0.001^{*}$ \\
\hline & E & -.0572 & .0371 & 0.542 \\
\hline \multirow[t]{4}{*}{$\mathbf{E}$} & A & .2111 & .0371 & $<0.001 *$ \\
\hline & B & .2262 & .0371 & $<0.001 *$ \\
\hline & $\mathrm{C}$ & .2212 & .0371 & $<0.001 *$ \\
\hline & D & .0572 & .0371 & 0.542 \\
\hline
\end{tabular}

$*_{\mathrm{p} \leq 0.05 \text { is considered statistically significant. }{ }^{*} * \text { Tukey HSD Test. }}$

Table 2: Comparison of Mean Value of Serum Catalase Among Various Groups

\begin{tabular}{lcccccc}
\hline \multirow{2}{*}{$\begin{array}{c}\text { Serum } \\
\text { catalase }\end{array}$} & Group A & Group B & Group C & Group D & Group E & p-value \\
\cline { 2 - 7 } & Mean \pm SD & Mean \pm SD & Mean \pm SD & Mean \pm SD & Mean \pm SD & \\
\hline
\end{tabular}

$* \mathrm{p} \leq 0.05$ is considered statistically significant. 


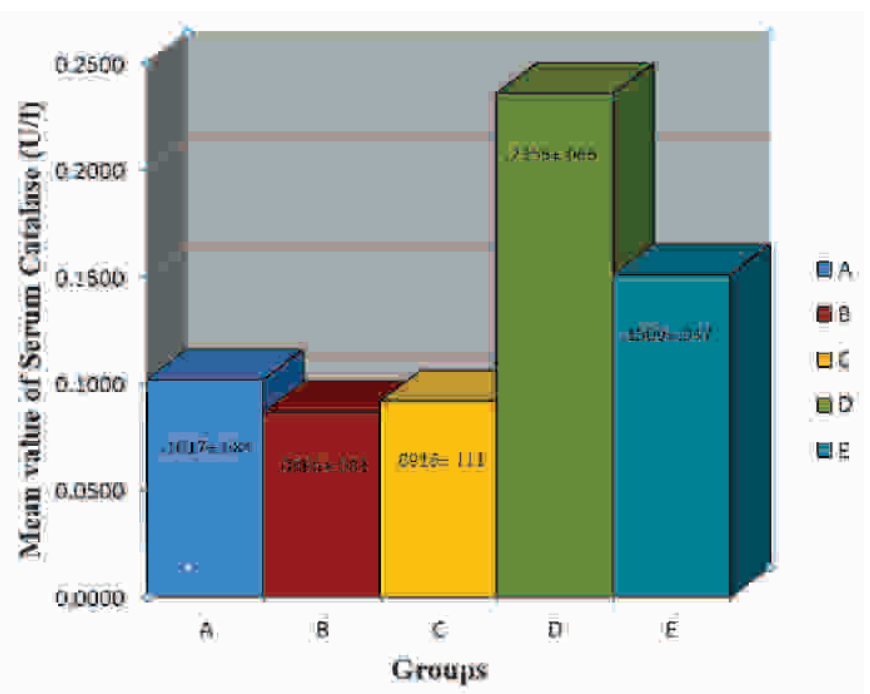

Fig. 1: Bar Chart Showing Comparison of Mean Value of Serum Catalase Among Various Groups

\section{Discussion}

PCOS is a condition with significant decrease in serum antioxidant and vitamin levels and there is an increased risk of oxidative stress. ${ }^{16}$ Catalase is an intracellular antioxidant that catalyzes the decrease of hydrogen peroxide to water and molecular oxygen and is essentially situated in cell peroxisomes and somewhat in the cytosol. ${ }^{17}$ This study shows a significant decrease in the activity of catalase in the disease control group B with PCOS. A deficiency of antioxidants could be due to decrease antioxidant intake, decrease synthesis of antioxidant enzymes, or increase antioxidant utilization. A significant decrease in the catalase activity was similarly reported in PCOS patients as compared to control. ${ }^{18,19}$ These findings are in accordance with our study. Therefore, the decrease in the catalase activity might be due to accumulation of ROS in which enzymatic activity was decreased by the state of oxidative stress in PCOS. Antioxidative supplementation has been shown to improve the PCOS like conditions. The present study assessed the role of antioxidant supplementation (AGE) on testosterone induced polycystic ovaries in prepubertal female rats and serum catalase as oxidative stress marker both in pre-intervention and post-intervention conditions.

After intervention it was clearly seen that there is marked increase in serum catalase enzyme in the group D as compared to other groups. It clearly shows that if polycystic ovaries were there and we treat them with antioxidants, conditions will clearly improves, whereas concomitant use of TP and AGE as in group
$\mathrm{C}$ might not improve the conditions of PCOS. The statistical analysis also revealed that if a PCOS like condition was there as in group E, without any intervention its body's own mechanism which improve the condition and produce a small amount of antioxidants to fight with the ROS. This study demonstrates that antioxidants are important in restoring and maintaining the oxidant and antioxidant balance in blood and tissues. It has been found that PCOS is associated with excessive oxidative stress and decreased antioxidant reserves and to improve these conditions we need secondary therapies to prevent the damage.

\section{Conclusion}

The involvement of antioxidants (AGE) in the management of polycystic ovaries may be helpful as secondary therapy to prevent the oxidative damage and may be used as a potential approach to overcome this disorder. Various studies have measured antioxidant markers to correlate oxidative stress and polycystic ovaries. This study strongly suggests that oxidative stress has a tremendous role in induction of polycystic ovaries.

\section{Conflict of Interest: None}

\section{References}

1. Van Houten EL, Kramer P, Mc Luskey A, Karels B, Axel P N, Themmen, Visser JA. Reproductive and Metabolic phenotype of a mouse model of PCOS. Endocrinology2012; 153(4): 0000-0000.

2. Franks S, Hardy K. Aberrant follicle development and anovulation in polycysticovary syndrome. Ann. Endocrinol 2010; 71:228-230.

3. Walters KA, Allan CM, Handelsman DJ. Rodent models for Human Polycystic Ovary Syndrome. Biology of Reproduction 2012; 86(5):149, 1-12.

4. Beloosesky R, Gold R, Almog B, Sasson R, Dantes A, Land-Bracha A, Hirsh L, Itskovitz-Eldor J, Lessing JB, Homburg R, Amsterdam A. Induction of polycystic ovary by testosterone in immature female rats: Modulation of apoptosis and attenuation of glucose/ insulin ratio. International Journal of Molecular Medicine 2004; 14:207-215.

5. Agarwal A, Gupta S, Sharma R. Oxidative stress and its implications in female infertility- a clinician's perspective. Reprod Biomed Online 2005; 11(5): 641-50.

6. Jeelani H, Ganie MA, Parvez T, Fatima Q, Kawa IA, Manzoor S, Rashid F. Oxidative stress biomarkers in polycystic ovary syndrome (PCOS). Precision 
Medicine 2017; Vol2(1): 30-38.

7. Pierce JD, Cackler AB, Arnett MG. Why should you care about free radicals? RN 2004; 67:38-42.

8. Al-Gubory KH, Fowler PA, Garrel C. The role of cellular reactive oxygen species, oxidative stress and antioxidants in pregnancy outcomes. Int $\mathrm{J}$ Biochem Cell Biol. 2010; 42: 1634-50.

9. Joo Jang H, Jin Lee H, Kyo Yoon D, Som Ji D, Han Kim J, Ho Lee C. Antioxidant and antimicrobial activities of fresh garlic and aged garlic by products extracted with different solvents. Food Sci Biotechnol 2018; 27(1)219-225.

10. Block E. The chemistry of garlic and onion. Sci. Am1985 252: 114-119.

11. Amagase H, Milner JA. Impact of various sources of garlic and their constituents on 7, 12-DMBA binding to mammary cell DNA. Carcinogenesis 1993; 14: 1627-1631.

12. Neil H, Sigali C. Garlic, its cardioprotective properties. Curr. Top. Lippidol1994; 5:6-10.

13. Carmia B, 2001.Antioxidant health effects of aged garlic extract. J. Nutr 2001; 131:1010S-1015S.

14. Banerjee SK, Maulik M, Mancahanda SC, DindaAK, Gupta SK, Maulik SK. 2.Dose- dependent induction of endogenous antioxidants in rat heart by chronic administration of garlic. Life Sci. 2002b; 70: 15091518.

15. Raji LO, Fayemi OE, Ameen SA, Jagum AT. The effects of Aqueous extract of Allium sativum(Garlic) on some aspects of reproduction in the female Albino rats(Wistar strain). Global Veterinaria 2012; 8(4): 414-420.

16. Al-Kateen MA, Ibrahim MA, Al-Jammal MHH, Shareef YS, Suleiman MA. Serum antioxidant vitamins changes in women with polycystic ovarian syndrome. J Bahrain Med Sci. 2010; 22: 68-71.

17. Oyebanji OG, Asaolu MF. Assessment of antioxidant status of women with polycystic ovarian syndrome. Asian Pac J Reprod 2020; 9(1): 9-15.

18. Al-Azzawie HF, HumadiEH. Oxidative stress and antioxidant mechanisms in a sample of Iraqi patients with polycystic ovary syndrome. Iraqi J Comm Med 2010; 3:196-200.

19. Kandasamy S, Ivagamasundari RI, Bupathy A. Sethubathy S, Gobal V. Evaluation of insulin resistance and oxidative stress in obese patients with polycystic ovary syndrome. IJABPT 2010; 2:391-398.
Authors Contribution
BY: Conceptionlization of Project
BY,HN: Data Collection
BY,HN: Literature Search
AS: Statistical Analysis
AS: Drafting, Revision
BY: Writing of Manuscript 